\title{
17. Studies on the Heredity of the Group-Specific Isoagglutinin in Normal Human Serum. IV.
}

On the Heredity of Anti-G Agglutinin.

By Tanemoto Furuhata, M.J.A., and Ei Matsunaga.

(Cumm. March 13, 1950.)

\section{Introduction.}

Antigen $\mathrm{C}$, not found in the blood cells of the group $\mathrm{O}$, but found in both group A and B, was named by Hibino in 1938. Iseki and Kobayashi were first ones to prove that the anti-C agglutinin existed in the human sera of group $O$ (1942). The following method was used to prove anti-C agglutinin.

The absorption of anti-B agglutinin in human serum of group $\mathrm{O}$ was first carried out with blood corpuscles $\left(B_{2} B_{3}\right)$ of a rabbit and then divided into two parts, one which was completely absorbed $\left(\beta_{\text {II }}\right)$, the other incompletely absorbed. 1/4 amount of the group $A$ blood was added to the upper clear liquid of the latter, left for 2 hours at room temperature and then again group B blood was added to the supernatant fluid. After absorption with blood corpucles of rabbit, the residual anti-B agglutinin, which was not absorbed with group $A$ blood is $\beta_{\mathrm{I}}$, while one which was completely absorbed contains $\beta_{\text {II }}$ and anti-C agglutinin (Table I).

Table I

Classification of anti-B agglutinin $\left(\beta_{\mathrm{I}}, \beta_{\mathrm{II}}\right)$ and demonstration of anti-C agglutinin $(\gamma)$ in the human serum of group $O$.

\begin{tabular}{|c|c|c|c|c|c|c|c|c|c|c|}
\hline \multirow{3}{*}{\multicolumn{3}{|c|}{$\begin{array}{l}\text { Anti-B and } \\
\text { Anti-C agglutinins }\end{array}$}} & \multirow{3}{*}{$\begin{array}{c}\text { Tested } \\
\text { by }\end{array}$} & \multicolumn{7}{|c|}{ Absorbed by } \\
\hline & & & & Control & \multirow{2}{*}{ 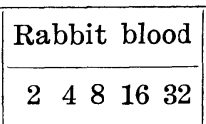 } & \multicolumn{5}{|c|}{$\begin{array}{c}\text { Rabitt blood \& human } \\
\text { blood of group A }\end{array}$} \\
\hline & & & & $\begin{array}{llllll}2 & 4 & 8 & 16 & 32\end{array}$ & & 2 & 4 & 8 & 1 & 32 \\
\hline \multirow{5}{*}{$\begin{array}{l}\text { Human } \\
\text { serum of } \\
\text { group }\end{array}$} & \multirow{2}{*}{ A } & $\beta_{\mathrm{II}}\left(\beta_{2} \beta_{3}\right)$ & \multirow{5}{*}{$\begin{array}{c}\text { The } \\
\text { blood of } \\
\text { group B }\end{array}$} & $\mathrm{HH}+\mathrm{H}++$ & ---- & & & & & \\
\hline & & $\beta_{\mathrm{I}}\left(\beta_{1} \beta_{2} \beta_{3}\right)$ & & $\mathrm{HH}+\mathrm{H}++$ & $H+--$ & & & & & \\
\hline & \multirow{3}{*}{$\mathrm{O}$} & $\alpha \beta_{I I}$ & & $\mathrm{HHH++}$ & --- & & & & & \\
\hline & & $\alpha \beta_{\mathrm{I}}$ & & $\mathrm{HtH+H}++$ & $H+---$ & H & + & & & - \\
\hline & & $\alpha \beta_{I I} \gamma($ anti-C) & & $\mathrm{HHHH}++$ & $H+---$ & - & - & - & & - \\
\hline
\end{tabular}

According to C. Kobayashi (1942) the antigen $\mathrm{C}$ is analyzed into partial antigen $\mathrm{C}_{\mathrm{I}}, \mathrm{C}_{\mathrm{II}}, \mathrm{C}_{\mathrm{III}}$ and as it is known that the blood corpuscles of rabbit have a structure of $\mathrm{B}_{\mathrm{II}}+\mathrm{B}_{\mathrm{III}}+\mathrm{C}_{\mathrm{II}}+\mathrm{C}_{\mathrm{III}}$, strictly 
speaking, the anti-C agglutinin found in human serum of the group $\mathrm{O}$ is the anti- $\mathrm{C}_{\mathrm{I}}$ agglutinin. The authors divided the ones with and without anti-C agglutinin with the above method and studied its hereditary relationship.

\section{Experimental Results.}

100 families with a totals of 420 persons in all were examined. Out of 125 persons with group O, 28 persons (22.4\%) had anti-C agglutinin. This percentage is almost identical with Kobayashi's $21.4 \%$, the frequency of anti-C agglutinin is $6.7 \%$. The agglutinin titers were all low $(2-8 \mathrm{x})$.

For the convenience of explanation, $\gamma$ stands for persons with anti-C agglutinin and 0 for those without anti-C agglutinin. The following 3 combinations obtained (Table II).

(1) Both parents without anti-C agglutinin $(0 \times 0)$.

There are 90 families in thisc ombination with a total of 195 children of which 9 persons (4.6\%) had anti-C agglutinin and 186 $(95.4 \%)$ without anti-C agglutinin.

(2) There were 9 families with one of the parents having anti-C agglutinin $(0 \times \gamma) .17(77.3 \%)$ children without and $5(22.7 \%)$ with anti-C agglutinin were born to these parents.

(3) Both parents with anti-C agglutinin $(\gamma \times \gamma)$.

Only one family with all three children $(100 \%)$ having anti-C agglutinin. The frequency of anti-C agglutinin being $7 \%$ is strictly identical with the results obtained by theoretical calculation.

With the above experiment, the authors have come to a conclusion that anti-C agglutinin is a hereditary character and the anti-C agglutinin is recessively inherited.

Table II

Heredity of anti-C agglutinin.

\begin{tabular}{c|c|c|c|c|c|c}
\hline \multirow{2}{*}{$\begin{array}{c}\text { Combina- } \\
\text { tion of } \\
\text { parents }\end{array}$} & $\begin{array}{c}\text { Number } \\
\text { of } \\
\text { families }\end{array}$ & \multicolumn{5}{|c|}{ Observed number and frequency of children and its } \\
\cline { 3 - 7 } calculated value
\end{tabular}

